\title{
The sense of God's presence in prayer
}

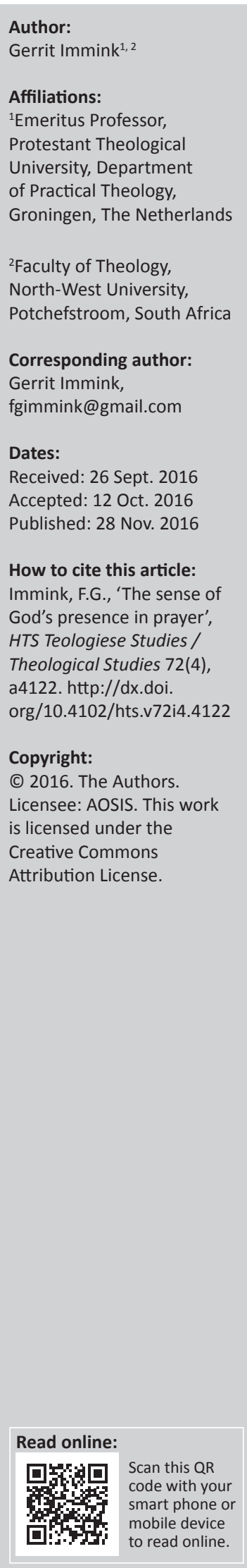

The awareness of God's presence and the experience of his works - key notions in practices of prayer - find reasonable doubt in our secular age. Meanwhile, there are, worldwide, many communities of faith where people enthusiastically pray and hold that they hear the voice of God. How can we understand this sense of God's presence?

In prayer, people express their hope and fear, and they do so with heart and mind. This subjective involvement is characteristic for prayer. At the same time, supplicants address God in the conviction that God is present and active. Critics of religion, however, criticise this 'external' realm of the divine and consider prayer a superstitious delusion. Passages of William James and John Calvin help us to get some insight in the 'object' of our religious consciousness. Furthermore, William Alston defends a non-sensory mystical perception of the divine. Using these insights, the author explores prayer as a conversation with God and reflects on the notion: hearing the voice of God.

\section{Introduction}

Prayer is a vital religious practice. In all world religions, prayer is most important and even people who are not religious sometimes pray. Although prayer is a basic religious act, it is a complex phenomenon and puzzling to comprehend. On the one hand, prayer is enacted in the concrete life of common people and expresses their needs and desires. On the other hand, it is a very specific religious act, given the fact that the praying person or community addresses God. One cannot describe prayer without describing the power of the God who is addressed (Chrétien 2000:149). In prayer, the God whom we address is thoroughly essential.

In this article, I will not present a phenomenology of prayer. Although I will describe some common insights in prayer, I will mainly write from a Christian perspective. My focus is on the sense of God in prayer. Prayer is rooted in the spiritual life of the praying person or community, and therefore the involvement of the human self is a basic factor in prayer. When people pray, they are involved with heart and mind. Furthermore, when people address God, they also have a sense of God. This sense may be weak or strong, but when people pray they believe that the God they address is alive, that $\mathrm{He}$ is active and present. This sense of God is also fundamental for practices of prayer.

In a predominantly secular society, many people have serious doubts concerning the truth of the sense of God. These doubts and critiques cause a true challenge for people who still practise their prayers. On the other hand, worldwide, there are many communities of faith where people enthusiastically and exuberantly pray. These emerging communities of faith, so it seems, form a contrast with the declining communities of faith in the secular regions of the globe. Because of the globalisation and migration, the secular and the religious subcultures meet one another more and more in one and the same public arena. Do the critical-sceptic and deep religious people have the same conception of the sense of God? And how does this sense of God function in prayer? These questions are relevant in today's society.

Moreover, mainline churches, which have a 'Western' theological tradition, mostly have a critical attitude towards the exuberant and high-spirited experiences of God in the emerging evangelical and Pentecostal Christian communities. In this situation, theological reflection on the sense of God in the life of prayer is very important for the discussion in the churches. It seems that, on the one hand, the sense of God's presence is fundamentally criticised by secular and naturalistic worldviews, while, on the other hand, many Christian communities strongly confirm that they hear the voice of God and that they feel His presence.

\section{Preliminary remarks on prayer in Christian contexts}

Before we discuss the theme of God's presence, we have a look at the broader concept of prayer. Ratschow (1984) presented the following phenomenological description: 
Under prayer so we understand the primarily 'personalistic', dialogical address (turn) of a human being to his God, to show him his own existence in his need or contentment as the domain of 'this' God's activity. [...] Hence, you can connect the prayer only with the appearance of the Deity. [...] The Deity proves in her epiphany to be the bulwark of 'salvation'. (p. 32)

For the development of my thoughts, four elements in this description of prayer are relevant:

- Prayers express the needs and the gratefulness of people in their daily life experiences.

- The praying person believes that the vicissitudes of life are within the control of God.

- Prayer is intrinsically related to the self-revelation and manifestation of God; and this revelation of God is believed to be salvific.

- Prayer is a personal encounter; it is a relationship where intentions and interactions can result in real change and renewal.

In his influential study Das Gebet, Friedrich Heiler once argued that prayer (in the prophetic tradition) gives expression to the dynamic relationship between the human being and God. Prayer, he says, is a personal bond, a reciprocal interaction, a dialogue and a communion between an I and a Thou (Heiler 1923:490). Prayer is not only a frame of mind, but an energetic act. Prayer is a practice that actualises the communion with God. Especially in the protestant tradition, prayer underlines the spiritual relationship between God and the human being. Calvin argues that prayer is an intercourse between God and men, 'by which they appear before Him and appeal to his promises' (Calvin 2002:524). We ask him through prayer what He already promised us. Prayer digs up those treasures which the Gospel discovers to the eye of faith. Augustine had the same line of thought: Lord, you will hear from me nothing but what you told me before (1939:388). When we invoke God, Calvin argues, He will reveal his presence, He will sustain us, prove his benevolence in the pardoning of our sins. We call upon him to manifest himself to us in all his perfections. (Calvin 2002:524) When we invoke God, He descends to us and proves his presence.

This personal and spiritual relationship and the experienced presence of God is one of the characteristic features of the Evangelical and Pentecostal churches. And prayer is, in fact, a core practice in the spirituality of all charismatic movements. The movement is characterised by its loud and spontaneous, simultaneous, and concerted or corporate prayer (Omenyo 2002:202-220). The nosy aspect of such prayers sounds like a cacophony of sounds.

It is not unlikely that the fast growth of Pentecostal churches in Africa related to an indigenous:

culture in which prayer life is quite natural (Immink 2012). According to Mbiti (1969):

African peoples communicate with God through prayer, pouring out their hearts before Him, at any time and in any place. The prayers are chiefly requests for material welfare, such as health, protection from danger, prosperity and even riches. Some prayers express gratitude to God; and in a few cases the people dedicate their belongings or activities to Him. Although most prayers are addressed directly to God, there are societies which offer prayers through the intermediary of the spirits, forefathers and living-dead. (pp. 64-65)

In the African context singing and dancing are indeed characteristic for worship. According to Mbiti (1969):

God is often worshipped through songs, and African peoples are very fond of singing. Many of the religious gatherings and ceremonies are accompanied by singing which not only helps to pass on religious knowledge from one person or a group to another, but helps create and strengthen corporate feeling and solidarity. (p. 67)

In the Western world, especially under the influence of the Enlightenment, the inner life and the human heart and mind play an important role in religious matters. Because human beings are intentionally involved, there is such a phenomenon as Geistesleben, a spiritual realm, an inner space, a conscious ' $\mathrm{I}$ ' as the centre of our actions, thoughts and desires. And it is this subjective and spiritual realm that is taken to be the cradle of religion. Under the influence of the critics of the Enlightenment, many theologians focused their attention more and more on the inner life of the believer: the mental state of the believer, the awareness of God as a psychological phenomenon. That means that according to western thought spiritual and religious performances are embedded in mental and psychological processes. This not necessarily implies western individualism. There is a growing insight that human beings live in relationship with others and with the world around them. People experience themselves as beingsituated-in-the-world. When people pray, they are expressing their relationship to a broader social and ontological realm. Hence, when people pray they bring forward the world in which they live; they bring forward their situation of life. Nonetheless, subjectivism and immediate contact with God remain important characteristics of Western prayer practices.

In the African context, the structure of thought is somewhat different. Jansen and Stoffels (2008) observe that for many African people there exists a kind of 'middle zone' in their cosmology:

This middle zone is neither completely this worldly nor completely otherworldly. It is a zone inhabited by spirits of ancestors (the living dead) and other spirit powers. To explain the issues of health, relationships, fortune, and success by naturalistic or secularized forces is to miss the central issue of power encounter that takes place in this middle zone. (p. 199)

She refers to other scholars (a. o. Mbiti) who have described the nature of the divinities. Ekeke and Ekeopara (2010) argue that these structures of thought are part and parcel of Africans:

Every child born into African culture grows with these concepts of God and he does not need to learn them because they are imbued in their folklores, myths, short stories, short sayings, proverbs, ceremonies and everything around them. (p. 213) 
What about the status of these divinities? According to Mbiti (1969), they:

have been created by God in the ontological category of the spirits. They are associated with Him, and often stand for His activities or manifestation either as personifications or as the spiritual beings in charge of these major objects or phenomena of nature. (pp. 75-76)

\section{Addressing God in a secular age}

In our secular age, addressing God as a Person and asking for divine intervention is out of the question. Our world is a disenchanted world. No God, no spirits, no supernatural power, no world of miracles or divine intervention. Especially the more educated sections of the population apprehend the world in terms of naturalism. As John Searle (1998) says:

For us, the educated members of society, the world has become demystified. Or rather, to put the point more precisely, we no longer take the mysteries we see in the world as expressions of supernatural meaning. We no longer think of odd occurrences as cases of God performing speech acts in the language of miracle. [...] If the supernatural existed, it too would have to be natural. (pp. 34-35)

This type of reasoning resulted in a demythologised mindset a sort of naturalistic worldview. If religion makes any sense at all, it can only be understood in terms of psychological mechanisms, or social and cultural processes. Meanwhile, the secular culture of the Western world produced an attitude of 'prayerlessness'. People do not know how to pray anymore. The dominant culture thwarts the spiritual awareness of God, and for many people it is hard to lift up their mind and heart beyond the so-called natural world.

One of the most influential philosophers that initiated this type of thinking was Immanuel Kant. Religion - if has a place at all - functions within the bounds of reason. The concept 'God' only makes sense in the realm of ethics:

Everything mankind fancies he can do, over and above good moral conduct, in order to make himself acceptable to God, is mere false worship of the Deity. (Kant 1838:228)

Religion is reduced to the realm of morality and personal piety or devotion. Religion only functions properly as long as we are aware of the fact that it is nothing more than the expression of a state of mind. There is no external existing God. This really has consequences for the practice of prayer:

Prayer, regarded as an internal formal worship of the Deity, and so as a mean of grace, is a superstitious delusion. It is nothing more than an uttered wish: declared moreover in the presence of a Being who stands in need of no information touching the inward sentiments of the declarant. By prayer there is consequently nothing done ... (Kant 1838:265)

To pretend to detect celestial influences within, is a kind of phrenzy, in which there may be method, [...] but which must notwithstanding be reprobated as a self-deception hurtful to religion. (Kant 1838:232)

Petitionary prayer in particular makes no sense at all. Asking God for a change in our human condition is utterly foolish.
Hoping for a change in the world around us, caused by God, is out of the question. What matters is our human intention, our Gesinnung. But if this would be true, how should we understand the almost natural inclination to pray? In the tradition of the Enlightenment, we find different sorts of explanations. Feuerbach (1881), for example, offers a fairly psychological explanation, which is even quite influential today:

Prayer is the self-division of man into two beings, - a dialogue of man with himself, with his heart. (p. 123)

Here human subject is seen as the source of religion. Of course, so runs the argument, religious performances such as prayer show up in human history. They belong so to say to the infrastructure of the human spirit (mind), but we must understand these phenomena as created by the human mind. However, in fact, there is no external reality like God that corresponds to these human projections. They are just what they are: creations of the mind. Further consequences are illusions.

It turns out that Feuerbach, although he supports the project of demythologising, does acknowledge the human need behind prayer. He deliberates how 'God' may play a role in the human self:

Pain must give itself utterance; involuntarily the artist seizes the lute that he may breathe out his sufferings in its tones. He soothes his sorrow by making it audible to himself, by making it objective; he lightens the burden which weighs upon his heart by communicating it to the air, by making his sorrow a general existence. But nature listens not to the plaints of man, it is callous to his sorrows. Hence man turns away from Nature, from all visible objects. He turns within, that here, sheltered and hidden from the inexorable powers, he may find audience for his griefs. Here he utters his oppressive secrets; here he gives vent to his stifled sighs. This open-air of the heart, this outspoken secret, this uttered sorrow of the soul, is God. God is a tear of love, shed in the deepest concealment over human misery. (Feuerbach 1881:121-122)

Feuerbach is not saying that God is working in the realm of the human heart but leaves nonetheless some room for 'Godlanguage' when our deepest desires and longings are at stake.

This critique on religion had an enormous impact on the modern theologians of the 19th and 20th centuries and influenced their ideas on prayer. The result was that (1) prayer was primarily understood as an expression of the inner life of the supplicant and (2) petitionary prayer was marginalised and gradually omitted (Immink 2016:41). Prayer was primarily seen as a means for moral improvement and spiritual perfection. According to Schleiermacher, prayer intensifies our sense of ultimate dependence (Schleiermacher 1983:188). But the idea that a human being by means of petitionary prayer can urge God to intervene in the world 'is a leap into magic' (Schleiermacher 1910:364). In this line of thought, Phillips (1981) once argued that: 
when deep religious people pray for something, they are not so much asking God to bring this about, but in a way telling Him the strength of their desires. They realize that things may not go as they wish, but they are asking to be able to go on living whatever happens. (p. 121)

But then the question arises: is this really what prayer is all about? Is not prayer a conversation with the God whose presence is felt and whose voice is heard?

\section{Human subjectivity and the sense of divine presence}

In prayer, people express their being-in-the-world, their hopes and fears, their worries and desires. Our human attitudes are embedded in emotions, volitions and bits and pieces of knowledge. All these feelings, moods and thoughts are shaped in a process of interaction with the world around us and the people we meet. In prayer, this whole world of awareness and understanding is activated in a personal and subjective way. People express their life and faith as-it-islived, and they do so in a personal address to God. They present themselves and their being-in-the-world for the face of God (Immink 2014:140-162).

Furthermore, prayer is performed in the presupposition that God, even though He may be hidden, is a living reality. As Dalferth states, 'Christian faith is faith in God, faith in God is faith in a living God, and for God to be living God must be present and active' (Dalferth 2006:39). Prayer, as communion with God, is performed in the conviction that the God addressed in prayer is present and active. How should we comprehend God's active involvement and presence?

In his book The Varieties of Religious Experience, the American philosopher and psychologist William James describes religious experiences of all kinds of people. In his study, he makes some remarkable comments on what he calls the 'objects' of our religious consciousness. Although this reality is 'unseen', it nevertheless has a very strong influence on us. He describes these experiences as the experience of a presence:

It is as if there were in the human consciousness a sense of reality, $a$ feeling of objective presence, a perception of what we may call 'something there', more deep and more general than any of the special and particular 'senses' by which the current psychology supposes existent realities to be originally revealed. (James 1985:73)

It is James' intention to show that the reality of the 'unseen' elicits a reaction in the lives of the faithful. Although the objects of religious experience are, according to James (1985), more or less abstract - not demonstrable in a concrete way they are nonetheless real:

It has been vouchsafed, for example, to very few Christian believers to have had a sensible vision of their Savior; [...] The whole force of the Christian religion, therefore, so far as belief in the divine personages determines the prevalent attitude of the believer, is in general exerted by the instrumentality of pure ideas, of which nothing in the individual's past experience directly serves as a model. (pp. 69-70)
That these experiences of presence are not demonstrable like 'normal' sense perceptions does, according to James, not make them illusory.

In his Institutes John Calvin also makes a few remarks on the human awareness of God's Presence. When we address God in prayer, Calvin says, we invoke the presence of his providence, of his power and his goodness; even more strongly, we invoke God to manifest himself to us in all his perfections. By prayer:

We invoke the presence of his providence to watch over our interests, of his power to sustain us when weak and almost fainting, of his goodness to receive us into favor, though miserably loaded with sin; in fine, call upon him to manifest himself to us in all his perfections. Hence, admirable peace and tranquility are given to our consciences ... (Calvin 2002:524)

In these various forms of presence, Calvin says, we experience God's-work-in-us. And this results in a certain mode of our state-of-mind: an amazing peace and tranquility. Hence, Calvin suggests that in prayer we invoke God's presence, and the praying person or community experiences this presence. We experience forgiveness and guidance.

The philosopher Alston has used the term 'mystical perception' to describe our human awareness of God. He reflects on those experiences 'in which it seems that God "appears" or "presents Himself" to one as so-and-so'. (Alston 1991:34) The faithful experience the presence and the activity of God in their lives: God's guidance, God's comfort, and so forth. Alston: 'Something is given to our awareness, which is not caused, by my own imagination, or memory, or abstract thought' (Alston 1991:37). The main significance of mystical perception is that it is an integral part of that personal relationship with God.

Alston maintains that God, or some activity or aspect of God, might be presented or given directly to our experience. Prior to our awareness of God, so he argues, there might be, under certain circumstances, a presentation, or a givenness of God. This presentation occurs prior to all conceptualisation and expression in language. Alston further holds that we might become aware of this givenness of God by some kind of nonsensory mystical perception. Why, so he says, suppose that the possibilities of experiential givenness are exhausted by the powers of our five senses? (Alston 1983:103-134) According to him, there is a kind of presentation that contrasts with conceptually structured perception and is also devoid of sensory content. It is a direct apprehension of God and not an interpretation that results from the perception of some other object than God:

Mystical perception is direct in the same way as (face-to-face) sense perception of objects; the object is not perceived through the perception of some other object, but there is nevertheless a distinction between the conscious experience involved and the object perceived. (Alston 1991:35) 
Thus, in this type of mystical perception there is no fusion between the human consciousness and God. But it is, nevertheless, a direct experiential awareness of God, originating in an act of presentation by God.

Arguing this way, Alston deals in a positive way with experiences of people who say to have felt the presence of God, people who saw God with the eyes of the soul. According to him, a believer can be in touch with God. This type of direct awareness or mystical perception, however, does not exclude other types of awareness, such as cognitive awareness by means of conceptual representation or indirect perception by the senses. But it does indicate that a believer can experience the presence of God and be in touch with God or with workings of God.

These thoughts are relevant for our understanding of prayer. We address God in prayer and we make contact with God. Prayer has performative power. When we address God, we are not simply imagining God in terms of a human phantasy no, there is a divine reality involved. We name God as an external reality - the living God. There is a real referent: the triune God. But we are also evoking God, contacting God, awaiting His Presence and his Activity. The praying person or community receives a sense of God's Presence, experiences the virtues of God such as His love and grace, and experiences comfort and forgiveness. Prayer activates spiritual life and intensifies the relationship with God.

\section{Hearing the voice of God}

When prayer is understood as a conversation with God, then there is some kind of reciprocity between the human being and God. Prayer entails an exchange of speaking and hearing. In the Bible, we find many reports of an encounter with God. As we can read in the Old Testament story of Samuel: The Lord came and stood there, calling as at the other times, 'Samuel! Samuel!' Then Samuel said, 'Speak, for your servant is listening' (1 Samuel 3:10). And in the New Testament we read of the apostle Paul: He fell to the ground and heard a voice say to him, 'Saul, Saul, why do you persecute me?' (Ac 9:4). De Moor and Korpel (2011) argue:

Direct communication between God and certain privileged people is confined mainly to descriptions of the early history of Israel. God addresses the first human beings directly in the Garden of Eden. He visits the patriarchs of Israel and engages in conversation with them. The Lord used to speak face to face to Moses, conversing with him as with a friend (Ex 33:11; Nm 12:8). (p. 148)

The idea of God speaking is fundamental to the Abrahamic religions. And not only in the sense that God has spoken to the prophets, in Jesus Christ, and in Holy Scripture, but also in the sense that he speaks to the faithful here-and-now. This hearing of the voice of God is more than believing that He has spoken in the prophets, or in Christ, or in the Holy Scriptures. It refers to some form of one's actual involvement in the relationship with God - an involvement that goes hand in hand with an awareness of God's presence and experiences of his workings. But how should we understand this hearing of the voice of God? Does not it sound ridiculous in a secular age?

Hearing a Word of God is a complex phenomenon. Usually hearing a Word of God is surrounded by practices of faith and meets specific criteria. As Terlouw says: 'Listening to God is performed in acts of reading, singing, faith-sharing and being silent' (Terlouw 2015:150). Believers themselves are mostly self-critical when they discern a voice of God in their lives. Authenticity and sincere discernment are important issues in the process of listening and hearing. I first make three rather general remarks on hearing the voice of God.

1. In the Christian tradition the Bible functions as an important criterion for understanding the Word of God. The stories and teachings provide a broad picture of what it means that God is speaking. The letter to the Hebrews says:

In the past God spoke to our ancestors through the prophets at many times and in various ways, but in these last days he has spoken to us by his Son, whom he appointed heir of all things, and through whom also he made the universe. (Heb 1:1-2)

In Jesus, God has spoken his deepest Word. Hence, the person of Jesus and his suffering and resurrection are understood as the Word of God. According to the Gospel of John, Jesus is the Word that became flesh. 'The Word became flesh and made his dwelling among us' (Jn 1). These sayings imply that the notions of 'God speaking' and 'the Word of God' have many connotations. As a matter of fact, practices of prayer very often go hand in hand with reading the Bible and participating in Bible study groups, and it is precisely the reading of the Bible that creates an aptness in the believer's mind for noticing the voice of God.

2. The community of believers provides an important environment for checks and balances in hearing the voice of God. The subjectivity of faith is not individual but rooted in the community of faith. According to Luhrmann (2012):

It is no easy matter to become confident that the God you imagine in the privacy of your mind exists externally in the world, talking back. In the struggle to give the invisible being its external presence, the congregation surrounds the individual and helps to hold the being out apart from the self, separate and external. It is the church that confirms that the invisible being is really present, and it is the church that reminds people week after week that the external invisible being loves them, despite all the evidence of the dreary human world. And slowly, the church begins to shape the most private reaches of the way congregants feel and know. (p. 131)

3. The praying person will examine herself whether this specific divine voice is human-made wishful thinking or an external voice. Terlouw (2015) found in her research on Evangelical Christians that discerning the voice of God is a serious challenge:

For all the practice, hearing God's voice remains a complicated discrimination task for these congregants. Many of them clearly experience themselves as getting better at picking out God's voice from the everyday flow of inner speech, but they also 
clearly experience the process as inherently ambiguous, and they hesitate to assume that their interpretations are accurate. [...] The more you believe that it is possible to experience God directly, the more uncertainty you invite about any particular claim to God's presence. If you allow the possibility that God speaks to humans, you believe that he speaks to human minds and human hearts, and inevitably, you question the accuracy of those human reporters more deeply than you question the accuracy of the scriptural text. (p. 70)

In addition to these theological reflections, I make a few remarks on the functioning of the human mind with respect to hearing the voice of God. First of all, it is important to distinguish between the noetic function of the human mind and the psycho-social processes by which the human mind operates. I hold that religious faith is part and parcel of our human noetic and psychological infrastructure. Faith in God is embedded in our psychic life. It comprises all kinds of emotions, insights and motivations. It is important, however, not to reduce religious faith to psychological processes or to a-state-of-mind. For believers have certain ideas about God and about God's relationship with the world. This is the more noetic function of the human mind: people have opinions about God, about Jesus Christ and the Holy Spirit. Mostly praying persons hold a set of beliefs about the God whom they address in prayer. Hence, we have to distinguish between, on the one hand, the level of the mental and psychological processes (the psycho-social dimension), and on the other hand the noetic content (let us say the dimension of beliefs, the confessional element). Praying persons hold, for example, that God is merciful, that He is just and holy, that $\mathrm{He}$ forgives our trespasses. When people pray, they address God with proper names (like the Lord) or definite descriptions that express these divine qualities and virtues.

In addition, a third dimension must be mentioned. When people address God, they name him as a person, they refer to him. God is addressed as a subsisting person. Hence, God is addressed as the Other whom they meet in conversation: God as a subsisting subject, as a speaking and answering person. This third dimension must be distinguished from the noetic content. Hence, in prayer the people who pray refer to a realm outside the human mind (Immink 2005:26-42, 238-266). This referential dimension is utterly crucial in prayer. It constitutes prayer.

Prayer is a religious performance and has an activating and actualising function. In prayer, the supplicant presents herself before the face of God. This act of presentation has a high degree of self-involvement: it is an intentional act where body, mind and soul cooperate. Prayer requires concentration and attention. When a supplicant expresses the desires and the blessings of the soul all the functions of the human mind are involved. Prayer not only activates the human self but also evokes God's presence. The opening words of prayer mostly name God or describe God's virtues in a doxological way. This naming and describing not only have a referential function but also an evoking power. The faithful believer hopes and prays that she will be touched by the God whom she addresses. In addressing God, the believer arrives at an awareness of God. This awareness may arouse all kinds of emotions and trigger diverse intentions. After all, Christian faith is an 'attitudinal belief'. However, in addressing God, supplicants also express their faith in God. And in doing so, the noetic function of the mind plays an important role. Prayer implies a dimension of content; it expresses 'articles of faith'. Prayers, performed in an act of concentration, are thoughtful. And, further, supplicants are aware of the objectdimension in the divine-human encounter: God is a Person, whom they expect to speak to them and to act upon them.

Consequently, when supplicants during their prayers become aware of God's presence (1), and when they experience workings from God (2), they are entitled to say that they hear the voice of God. The way in which people perceive God may diverge. Some will label the voice of God as an inner working of the Spirit, while others will understand it as a mystical perception of God's virtues and workings. It is interesting to notice that the vocabulary that is used to describe this 'Touch of God' varies between different groups of Christians. Evangelical and Pentecostal Christians talk very realistic and almost materialistic about their hearing the voice of God. According to Terlouw (2015):

Bible texts, cards, things, dreams and circumstances figure in the believers' experience as signs from God. Experiences of divine communication do not pop into their mind, but much rather happen to them. (p. 120)

The more liberal Christians, on the other hand, hold that God speaks to us through our inner spiritual life and through moral commandments. According to Herrmann (1892:199204), Christians experience the love of God when they have an awareness of forgiveness and they sense God when they see moral improvement. Be these differences as they are, prayer is essential in the human encounter with God and an important instrument to hear the voice of God. Prayer is, according to James (1985), religion in act:

Prayer, by which I understand no vain exercise of words, no mere repetition of certain sacred formulae, but the very movement itself of the soul, putting itself in a personal relation of contact with the mysterious power of which it feels the presence... (p. 444)

\section{Acknowledgements Competing interests}

The author declares that he has no financial or personal relationships which may have inappropriately influenced him in writing this article.

\section{References}

Alston, W.P., 1983, 'Christian experience and Christian belief', in A. Plantinga \& N. Wolterstorff (eds.), Faith and rationality. Reason and belief in God, pp. 103134, University of Notre Dame Press, Notre Dame.

Alston, W.P., 1991, Perceiving God. The epistemology of religious experience, Cornell University Press, Ithaca, NY.

Augustinus, A., 1939, Confessiones: Latijnsche tekst met vert. en inl. van A. Sizoo, Meinema, Delft. 
Calvin, J., 2002, Institutes of the Christian religion, [translation Henry Beveridge], Christian Classics Ethereal Library, Grand Rapids, MI, viewed 11 October 2016, from http://www.ccel.org/ccel/calvin/institutes.html

Chrétien, J.-L., 2000, 'The wounded word. The phenomenology of prayer', in D. Janicaud (ed.), Phenomenology and the 'theological turn': The French debate, pp. 147-175, Fordham University Press, New York.

Dalferth, I.U., 2006, Becoming present. An inquiry into the Christian sense of the presence of God, Peeters, Leuven.

Ekeke, E.C. \& Ekeopara, C.A., 2010, 'God, divinities and spirits in African traditional religious ontology', American Journal of Social and Management Sciences. http:// dx.doi.org/10.5251/ajsms.2010.1.2.209.218

Feuerbach, L., 1881, The essence of Christianity, transl. M. Evans, Trübner \& Co. Ludgate Hill, London.

Heiler, F., 1923, Das Gebet: Eine religiongeschichtliche und religionpsychologische Untersuchung, Verlag von Ernst Reinhardt, München.

Herrmann, W., 1892, Der Verkehr des Christen mit Gott. Im Anschluss an Luther dargestellt, Gotta, Stuttgart.

Immink, F., 2005, Faith. A. Practical theological reconstruction, Eerdmans, Grand Rapids, MI.

Immink, F., 2014, The touch of the sacred: The practice, theology, and tradition of Christian worship, Eerdmans, Grand Rapids, MI.

Immink, F.G., 2012, 'The invocation of the holy spirit', Revue Congelaise de Theologie Protestante 21(2012), 281-292.

Immink, G., 2016, Bidden in het besef van Gods tegenwoordigheid, Boekencentrum, Zoetermeer.
James, W., 1985, The varieties of religious experience. A study in human nature, Collins Fount Paperbacks, Glasgow.

Jansen, M. \& Stoffels, H. (eds.), 2008, A moving God. Immigrant Churches in the Netherlands, LIT, Zürich.

Kant, I., 1838, Religion within the boundary of pure reason, transl. W.J. Semple, Thomas Clark, Edinburgh.

Korpel, M.C.A. \& De Moor, J.C., 2011, The silent God, Brill, Leiden.

Luhrmann, T.M., 2012, When God talks back. Understanding the American evangelical relationship with God, Alfred A. Knopf, New York.

Mbiti, J.S., 1969, African religions and philosophy, Heinemann, London.

Omenyo, C.N., 2002, Pentecost outside Pentecostalism: A study of the development of charismatic renewal in the main line churches of Ghana, Boekencentrum, Zoetermeer.

Phillips, D.Z., 1981, The concept of prayer, The Seaburry Press, New York.

Ratschow, C.H., 1984, 'Gebet I, Religionsgeschichtlich', in G. Krause \& G. Müller (Hrsg.), Theologische Realenzyklopädie 12, pp. 31-34, De Gruyter, Berlijn.

Schleiermacher, F., 1910, Der Christliche Glaube nach den Grundsätzen der evangelischen Kirche im Zusammenhang dargestellt, Otto Hendel, Halle.

Schleiermacher, F., 1983, Die praktische Theologie nach den Grundsätzen der evangelischen Kirche im Zusammenhang dargestellt [Berlin, 1850], photomechanischer Nachdruck, Walter de Gruyter, Berlin.

Searle, J.R., 1998, Mind, language and society, philosophy in the real world, Basic Books, New York.

Terlouw, I., 2015, Real faith. Performativity and materiality in the personal relationship with Jesus of Evangelical Protestants, Eburon, Delft. 